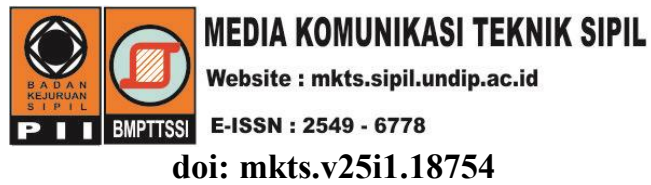

\title{
Model Hubungan Kapasitas Rekatan Balok Beton Bertulang yang Diperkuat GFRP-S terhadap Lama Perendaman Air Laut
}

\author{
"Mufti Amir Sultan', Rudy Djamaluddin² \\ ${ }^{1}$ Program Studi Teknik Sipil, Universitas Khairun, Ternate \\ ${ }^{2}$ Jurusan Teknik Sipil, Universitas Hasanuddin, Makassar \\ ${ }^{*}$ muftiasltn@unkhair.ac.id
}

Received: 29 April 2018 Revised: 11 Maret 2019 Accepted: 13 Maret 2019

\begin{abstract}
The construction of structures with reinforced concrete materials in coastal environments will face constraints in the form of chloride influences which can lead to a decrease in strength and even damage. One of the most popular reinforcement methods today is using a corrosion resistant Glass Fiber Reinforced Polymer (GFRP) material. This study was conducted to investigate the behavior of GFRP-S rectifying capacity in reinforced concrete beam reinforcement in 1, 3, 6, and 12 months. The test specimens consist of 10 reinforced beams with dimensions (15x20x330) cm that has been reinforced with GFRP-S in the bending area. Beams without immersion symbolized $B_{0}$, immersion $1,3,6$, and 12 months each given symbols $B_{1}, B_{3}, B_{6}$ and $B_{12}$. The test specimen is loaded statically until it fails. To record the data when testing is installed strain gauge and LVDT. From the result of the research, it can be seen that there is a decrease of GFRP-S rectification capacity in the test specimen after soaking in seawater. The value of the decrease in the capacity of the bonding can be predicted by using the equation $K R_{t}=K R_{0} e^{-0.0072 t}$
\end{abstract}

Keywords: GFRP-S, bonding capacity, seawater

\begin{abstract}
Abstrak
Pembangunan struktur dengan material beton bertulang pada daerah lingkungan pantai akan menghadapi kendala berupa pengaruh klorida yang dapat mengakibatkan penurunan kekuatan bahkan kerusakan. Salah satu cara perkuatan yang populer saat ini dengan menggunakan material Glass Fiber Reinforced Polymer (GFRP) yang tahan korosi. Penelitian ini dilakukan untuk menyelidiki perilaku kapasitas rekatan GFRP-S pada perkuatan balok beton bertulang yang direndam dalam air laut selama 1, 3, 6, dan 12 bulan. Benda uji terdiri dari 10 buah balok bertulang dengan dimensi (15x20x330) cm yang telah diperkuat dengan GFRP-S pada daerah lentur. Balok tanpa perendaman disimbolkan $B_{0}$, perendaman 1, 3, 6 dan 12 bulan masing-masing diberi symbol $B_{1}, B_{3}, B_{6}$ dan $B_{12}$. Benda uji diberi beban statik sampai gagal. Untuk merekam data-data pada saat pengujian dipasang strain gauge dan LVDT. Dari hasil penelitian terlihat bahwa terjadi penurunan kapasitas rekatan GFRP-S pada benda uji setelah direndam dalam air laut. Nilai penurunan kapasitas rekatan dapat diprediksi dengan menggunakan persamaan $K R_{t}=K R_{0} e^{-0,0072 t}$.
\end{abstract}

Kata kunci: GFRP-S, kapasitas rekatan, air laut

\section{Pendahuluan}

Saat sekarang pembangunan konstruksi sipil semakin berkembang seiring dengan peningkatan kebutuhan manusia. Pembangunan pada daerah pantai atau bahkan di dalam laut semakin meningkat seperti pembangunan bangunan, jembatan, jalan raya atau jalan tol, dermaga dan penahan gelombang. Struktur beton bertulang yang tidak dilindungi atau dekat dengan laut mungkin dipengaruhi oleh korosi, jika tidak ada tindakan pemeliharaan dan pencegahan sehingga dapat menyebabkan keruntuhan.

Beberapa alternatif telah dikembangkan seperti coating pada tulangan dengan menggunakan epoxy, penggunaan tulangan galvanis, namun bahan tersebut mempunyai harga yang relatif mahal. Dalam beberapa dekade terakhir dikembangkan material Fiber Reinforced Plastics (FRP) telah 
diterima sebagai bahan alternatif untuk penguatan baja konvensional (Balamuralikrishnan \& Jeyasehar, 2009). FRP telah diterapkan pada beberapa struktur sebagai perkuatan untuk beton pada struktur baru atau struktur yang telah lama (Hamid \& Hutchinson, 2001). Penggunaan FRP sebagai perkuatan eksternal pada balok beton bertulang meningkatkan beban retak awal, beban leleh, dan puncak (Hong et al., 2014). Perkuatan balok beton bertulang dengan pemasangan GFRP tipe lembaran pada bagian bawah balok dapat meningkatkan kapasitas lentur balok dibandingkan dengan balok kontrol atau tanpa perkuatan (Meikandaan \& Murthy, 2017). FRP dapat digunakan untuk memperkuat atau merehabilitasi balok beton bertulang dengan bukaan pada balok (Mondal \& Gautam, 2011). Penggunaan FRP pada struktur yang telah mengalami penurunan kekuatan akibat korosi di mana balok yang diperkuat dengan FRP akan meningkatkan kekakukan, batas leleh dan kekuatan batasnya (Rose et al., 2009). Penggunaan GFRP tipe lembaran sebagai perkuatan pada balok beton bertulang yang telah terbebani hingga leleh tulangan memiliki kapasitas lentur yang lebih tinggi dari balok aslinya (Djamaluddin \& Hino, 2011).

Kegagalan yang sering terjadi pada balok perkuatan dengan serat FRP seperti diilustrasikan pada Gambar 1.

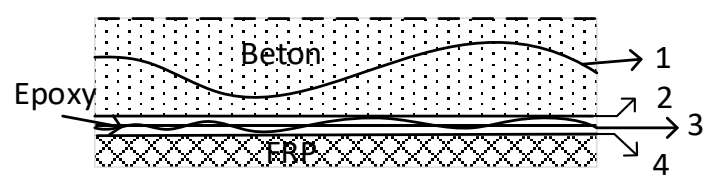

\section{Gambar 1. Kegagalan balok perkuatan FRP}

Jenis kegagalan pada titik 1 yaitu terlepasnya ikatan antara beton (delaminasi kohesif), titik 2 terlepasnya rekatan antara epoxy dengan beton (delaminasi adhesive), titik 3 terlepasnya ikatan antara epoxy (delaminasi kohesif) dan titik 4 terlepasnya rekatan antara epoxy dan GFRP-S (delaminasi adhesive).

Beberapa penelitian mengenai kegagalan balok perkuatan FRP antara lain: Kegagalan dengan lepasnya rekatan FRP dengan permukaan beton dimulai pada lokasi retak lentur yang kemudian merambat ke ujung FRP (Teng \& Chen, 2007). Kegagalan dengan lepasnya rekatan FRP pada permukaan beton sering dijumpai pada balok perkuatan FRP (Guo et al., 2005).

Karena kelebihannya, bahan FRP menjadi solusi yang menjanjikan untuk pada daerah yang mempunyai korosi tinggi seperti pada daerah pantai. Namun lingkungan laut berdampak terhadap stuktur seperti beberapa penelitan berikut ini.
Dimana lingkungan laut berdampak terhadap kekuatan balok beton bertulag yang telah diperkuat dengan GFRP (Sultan et al., 2015). Kapasitas lentur balok beton bertulang yang telah diperkuat GFRP$S$ pada sisi tarik balok mengalami penurunan kapasitas setelah direndam dalam air laut selama 6 bulan (Sultan et al., 2016).

Kapasitas rekatan antara FRP dengan balok beton bertulang mengalami penurunan kapasitas setelah direndam dalam air laut (Sultan \& Djamaluddin, 2017). Namun perlu penelitian lebih lanjut untuk memodelkan penurunan kapasitas rekatan FRP dan beton sehingga dapat diprediksi berapa besar penurunan kapasitas rekatan dengan waktu.

Penggunaan GFRP sebagai tulangan pada balok beton bertulang mempunyai kapasitas lentur yang lebih baik dibandingkan dengan menggunakan tulangan baja akibat pengaruh lingkungan jangka panjang (Park et al., 2014).

Untuk memenuhi permintaan FRP telah dikembangkan dalam berbagai bentuk seperti bar, strip, kabel serta lembaran. Penamaan FRP sesuai dengan material dasar pembentuknya: aramyd fiber reinforced plastic (AFRP), glass fiber reinforced plastics (GFRP) dan carbon fiber reinforced plastic (CFRP). Gambar 2 memperlihatkan GFRP tipe lembaran yang digunakan dalam penelitian ini. Penggunaan GFRP dengan pertimbangan harga relatif lebih murah dibandingkan dengan kedua serat yang lain.

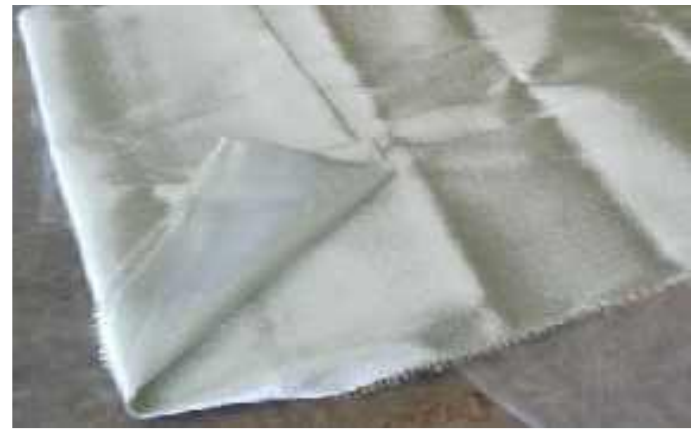

Gambar 2. GFRP tipe lembaran

\section{Metode Penelitian}

\section{Benda uji}

Benda uji yang digunakan terdiri dari 10 balok beton bertulang. Penampang melintang benda uji adalah 15 x $20 \mathrm{~cm}$ dengan panjang $330 \mathrm{~cm}$. Tulangan yang digunakan 2D14 di sisi tarik (sisi bawah) dan $2 \phi 6$ pada daerah tekan (sisi atas). Tulangan sengkang pada jarak $1 / 4 \mathrm{~L}$ dari tumpuan kiri dan kanan digunakan $\phi 10-77$, pada daerah $1 / 2 \mathrm{~L}$ 
digunakan $\phi 10-200$. Detail benda uji ditunjukkan pada Gambar 3. Mutu beton dan mutu baja yang digunakan masing-masing adalah $25 \mathrm{MPa}$ dan 421,27 MPa.

Variasi benda uji dapat dilihat pada Tabel 1, Simbol benda uji $\mathrm{B}_{\mathrm{y}-\mathrm{i}}$, y dimana menyatakan waktu perendaman dan i menyatakan urutan benda uji.

Perendaman 0 bulan atau tanpa perendaman sebanyak dua buah $\left(\mathrm{B}_{0-1}\right.$ dan $\left.\mathrm{B}_{0-2}\right)$, perendaman satu bulan sebanyak dua buah $\left(\mathrm{B}_{1-1}\right.$ dan $\left.\mathrm{B}_{1-2}\right)$, perendaman tiga bulan sebanyak dua buah $\left(\mathrm{B}_{3-1}\right.$ dan $B_{3-2}$, perendaman enam bulan sebanyak dua buah $\left(\mathrm{B}_{6-1}\right.$ dan $\left.\mathrm{B}_{6-2}\right)$ dan perendaman 12 bulan sebanyak dua buah ( $\mathrm{B}_{12-1}$ dan $\left.\mathrm{B}_{12-2}\right)$.

Tabel 1. Variasi benda uji

\begin{tabular}{ccc}
\hline No & Benda uji & Waktu perendaman (bulan) \\
\hline 1 & $\mathrm{~B}_{0-1}$ & 0 \\
2 & $\mathrm{~B}_{0-2}$ & 0 \\
3 & $\mathrm{~B}_{1-1}$ & 1 \\
4 & $\mathrm{~B}_{1-2}$ & 1 \\
5 & $\mathrm{~B}_{3-1}$ & 3 \\
6 & $\mathrm{~B}_{3-2}$ & 3 \\
7 & $\mathrm{~B}_{6-1}$ & 6 \\
8 & $\mathrm{~B}_{6-2}$ & 6 \\
9 & $\mathrm{~B}_{12-1}$ & 12 \\
10 & $\mathrm{~B}_{12-2}$ & 12 \\
\hline
\end{tabular}

Pemasangan GFRP-S dilakukan setelah bahan uji dicuring selama 28 hari dengan menggunakan metode wet lay-up. Pemasangan GFRP-S pada balok beton bertualang terdiri dari lima tahapan yaitu: tahap pertama, memotongan GFRP-S sesuai ukuran, pada penelitian ini menggunakan GFRP-S sepanjang $300 \mathrm{~cm}$ sebanyak dua lapis, tahap kedua, menghalusan permukaan beton yang akan dipasangi GFRP-S dengan menggunakan gurinda, tahap ketiga, mencampur epoxy Tyfo S komponen A dan komponen B dengan perbandingan 2:1, tahap keempat, epoxy yang telah dicampur dioleskan pada pada permukaan beton dengan menggunakan kuas rol, dan tahap kelima menempelkan GFRP-S pada benda uji menggunakan metode wet lay-up.

Metode wet lay-up merupakan metode pemasangan FRP, dimana FRP yang akan dipasang perlu dibasahi sebelumnya terlebih dahulu dengan epoxy untuk selanjutnya dilapisi pada benda uji yang akan diperkuat. Posisi penempelan GFRP-S berada pada daerah sisi tarik benda uji balok. Setelah GFRP-S diletakkan pada permukaan benda uji balok, bahan perekat kembali diberikan di atas lapisan GFRP-S karena dalam penelitian ini digunakan dua lapisan GFRP-S untuk memastikan kondisi kerusakan yang terjadi. Setelah pemasangan GFRP-S telah selesai, maka benda uji didiamkan selama 36 jam. Setelah itu benda uji siap dibawa ke kolam perendaman. Ketika benda uji direndam maka saat tersebut merupakan awal penentuan waktu untuk pengamatan.

\section{Bak perendaman}

Bak yang digunakan sebagai tempat perendaman benda uji berukuran $8 \mathrm{~m}$ x $4 \mathrm{~m}$ dengan kedalaman 1 $\mathrm{m}$. Kolam ini juga diberi atap untuk menghindari masuknya air yang hujan yang dapat menyebabkan kadar garam dari air laut tersebut berkurang. Detail gambar kolam perendaman dapat dilihat dalam Gambar 4.

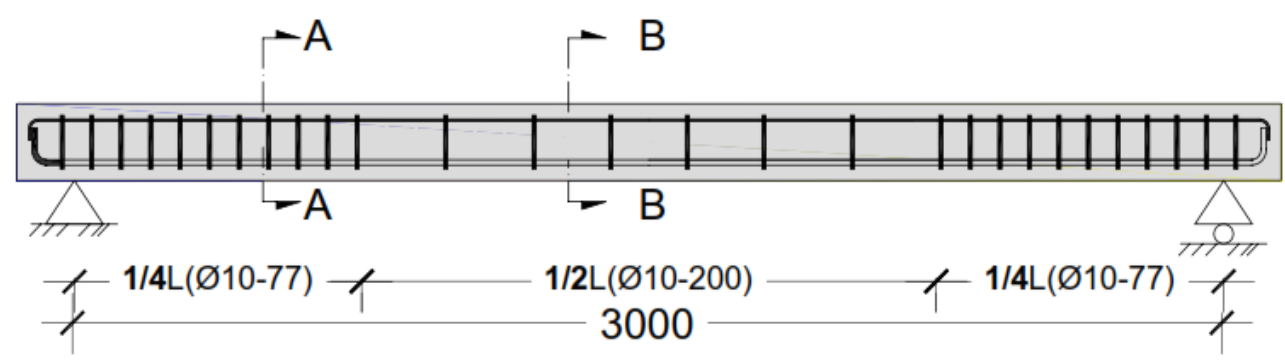

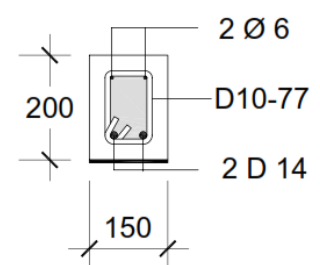

SEC. A-A

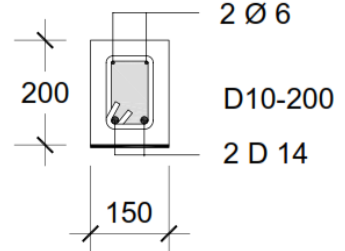

SEC. B-B

Gambar 3. Detail benda uji 

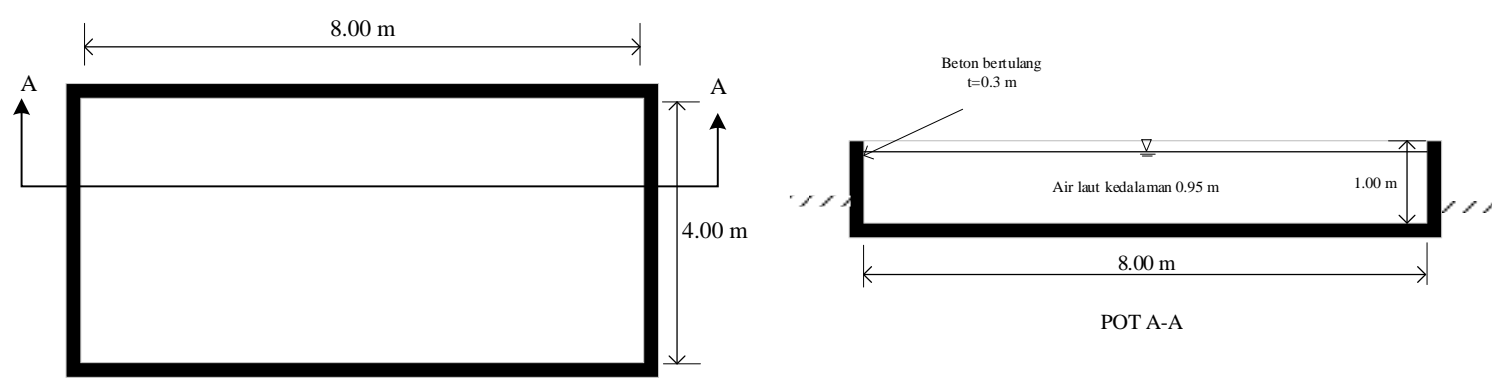

POT A-A

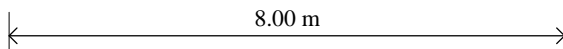

Gambar 4. Kolam perendaman

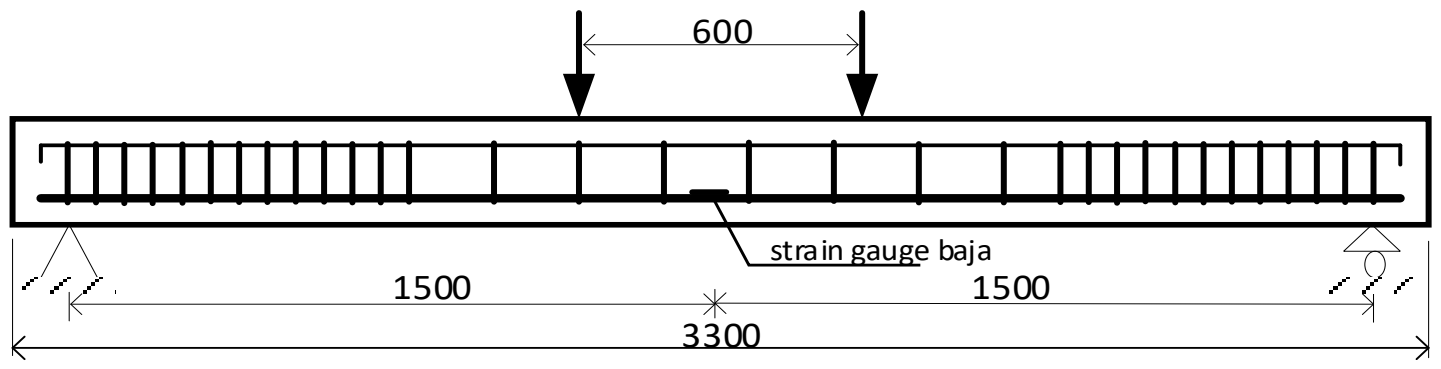

Gambar 5. Penempatan strain gauge baja

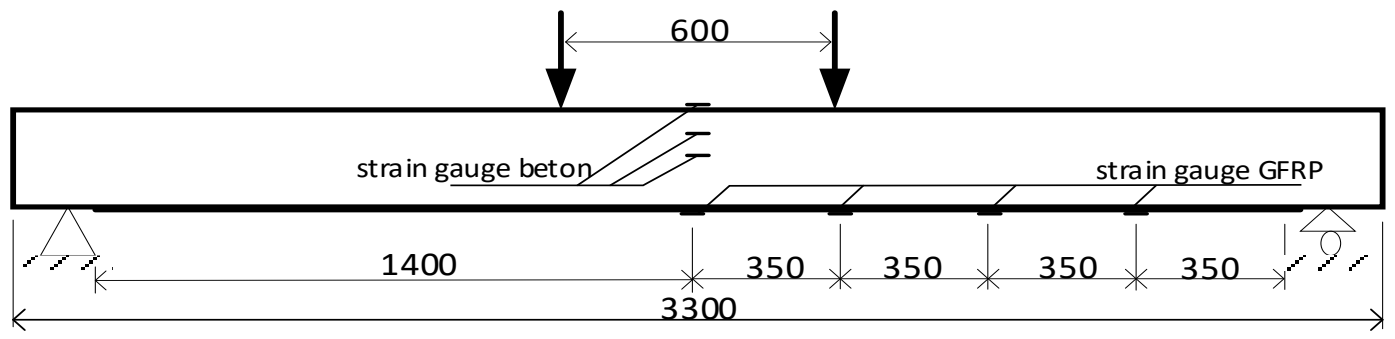

Gambar 6. Penempatan strain gauge beton dan strain gauge GFRP

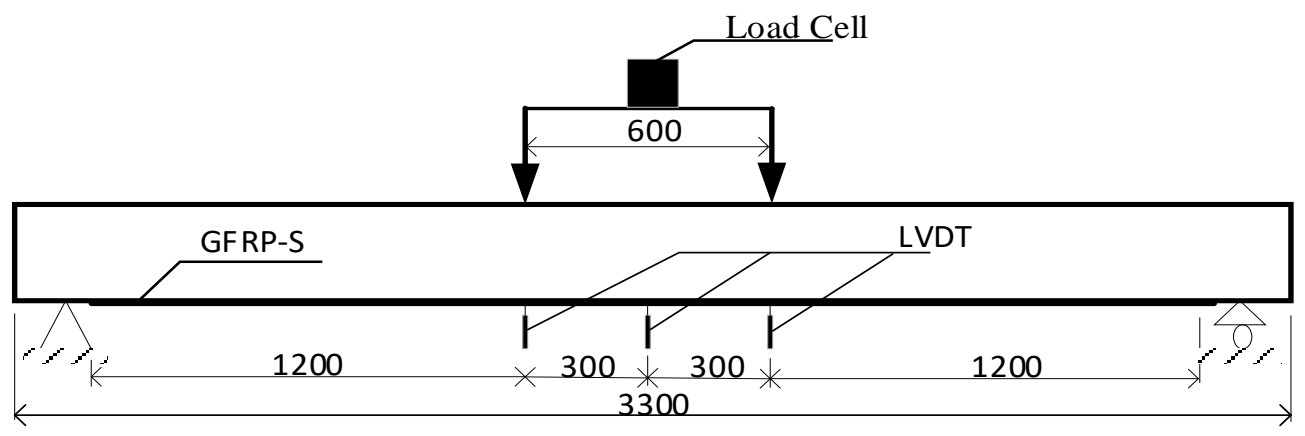

Gambar 7. Setup benda uji

\section{Setup pengujian}

Pada setiap benda uji dipasang strain gauge tipe FLA-2-11 sebanyak dua buah pada baja tulangan di daerah tarik. Strain gauge tipe PL-60-11 dipasang pada beton dipasang sebanyak tiga buah, yaitu pada daerah tekan benda uji, daerah $1 / 2$ tinggi benda uji dan pada daerah $1 / 4$ tinggi benda uji ditengah bentang. Strain gauge tipe FLA-2-11 dipasang pada GFRP-S sebanyak empat buah yang pemasangannya dari posisi $1 / 2 \mathrm{~L}$ benda uji dan menyebar pada masing-masing jarak $35 \mathrm{~cm}$ sampai ke ujung GFRP-S, posisi strain gauge ditunjukkan pada Gambar 5 dan Gambar 6. Setup pengujian 
diilustrasikan pada Gambar 7, untuk merekam data lendutan dipasang LVDT sebanyak tiga buah vertikal pada tengah bentang dan pada titik dibawah point load. Untuk membaca lebar retak digunakan phi gauge. Phi gauge ini dipasang pada bagian yang retak setelah retak pertama terlihat pada benda uji.

Pengujian dilakukan dengan two point load, pembebanan yang bersifat monotonik dengan kecepatan ramp actuator konstan sebesar 0,05 $\mathrm{mm} / \mathrm{dt}$ sampai benda uji mengalami kegagalan. Seluruh instrument yang dipasang pada benda uji selanjutnya dihubungkan ke data logger dan komputer untuk merekam data pengujian.

Pengamatan terhadap benda uji terus dipantau secara visual, terutama terhadap perkembangan retak yang terjadi akibat bertambahnya beban, juga terhadap perilaku keruntuhan yang terjadi. Pembebanan dilakukan hingga mencapai beban ultimit. Momen lentur pada penelitian ini dapat diperoleh dengan menggunakan persamaan 1 .

$\mathrm{M}=0.8019+0.6 \mathrm{P}$

Dimana $\mathrm{P}$ adalah beban yang yang diberikan pada benda uji $(\mathrm{kN})$

\section{Hasil dan Pembahasan}

\section{Kapasitas lentur maksimum}

Tabel 2 menunjukkan bahwa kapasitas lentur maksimum rata-rata benda uji mengalami penurunan setelah direndam dengan air laut, besar beban maksimum rata-rata berturut-turut dari $\mathrm{B}_{0}$, $\mathrm{B}_{1}, \mathrm{~B}_{3}, \mathrm{~B}_{6}$, dan $\mathrm{B}_{12}$ adalah 3,42 ton, 3,37 ton, 3,36 ton, 3,34 ton, dan 3,33 ton. Prosentase penurunan kapasitas lentur setelah benda uji direndam dengan air laut sebesar $2,63 \%$.

Tabel 2. Kapasitas lentur maksimum rata-rata

\begin{tabular}{ccc}
\hline No & Benda uji & Kapasitas lentur (ton.m) \\
\hline 1 & $\mathrm{~B}_{0}$ & 3,42 \\
2 & $\mathrm{~B}_{1}$ & 3,37 \\
3 & $\mathrm{~B}_{3}$ & 3,36 \\
4 & $\mathrm{~B}_{6}$ & 3,34 \\
5 & $\mathrm{~B}_{12}$ & 3,33 \\
\hline
\end{tabular}

\section{Kapasitas rekatan GFRP-S}

Pada Gambar 8 dapat dilihat pada di awal tahap pembebanan, kurva memilik bentuk non linier. Regangan menurun seiring dengan bertambahnya jarak tengah bentang. Seiring peningkatan beban, grafik cenderung untuk mencapai bentuk linear. Pada tingkat beban tertentu, kurva distribusi regangan menjadi linear yang berarti sendi mulai gagal. Ini sesuai dengan hubungan kapasitas rekatan sepanjang bagian permukaan GFRP yang menerima pembebanan.

Kegagalan rekatan terjadi pada tahap yang ditunjukkan oleh distribusi regangan, bentuk kurva regangan menjadi horizontal pada awal kegagalan rekatan yang berarti bahwa tulangan sudah tidak dapat mentransfer beban, sehingga pembebanan ditransfer ke GFRP. Strain gauge yang jauh dari tengah bentang membaca regangan seiring dengan meningkatnya pembebanan, ini berarti transfer beban pada GFRP bergeser sepanjang permukaan GFRP dengan beton sampai terjadi proses debonding.

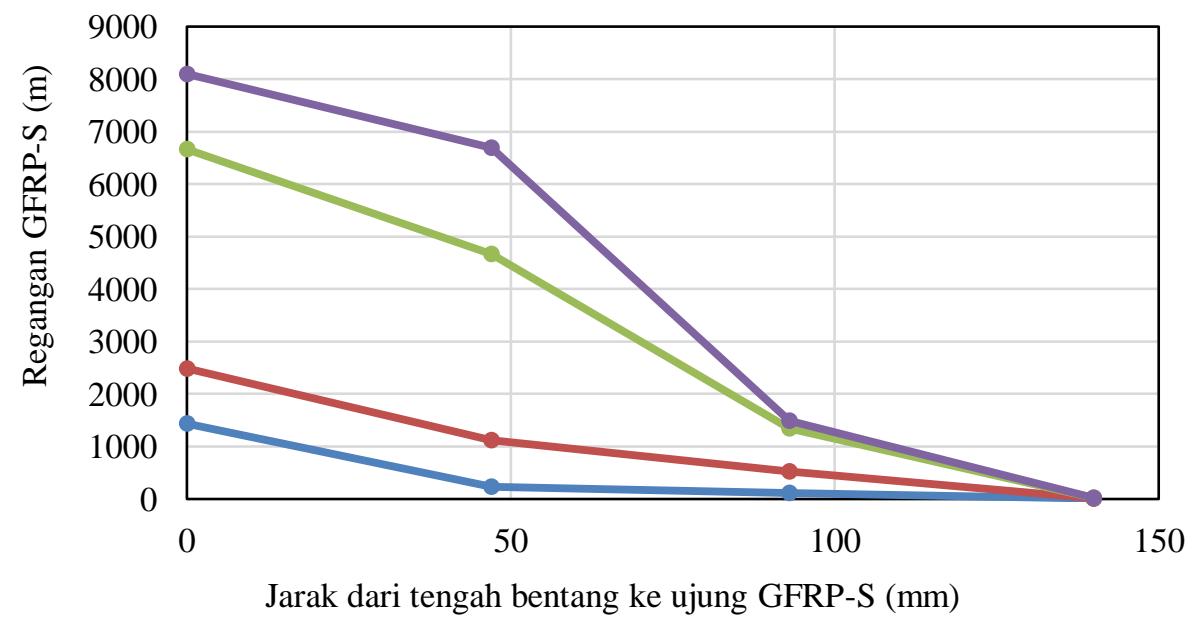

$\longrightarrow \mathrm{P}=1,02$ ton $\longrightarrow \mathrm{P}=2,04$ ton $\longrightarrow \mathrm{P}=4,08$ ton $\longrightarrow \mathrm{Pmax}=4,41$ ton

Gambar 8. Distribusi regangan GFRP-S pada benda uji $B_{0}$ 


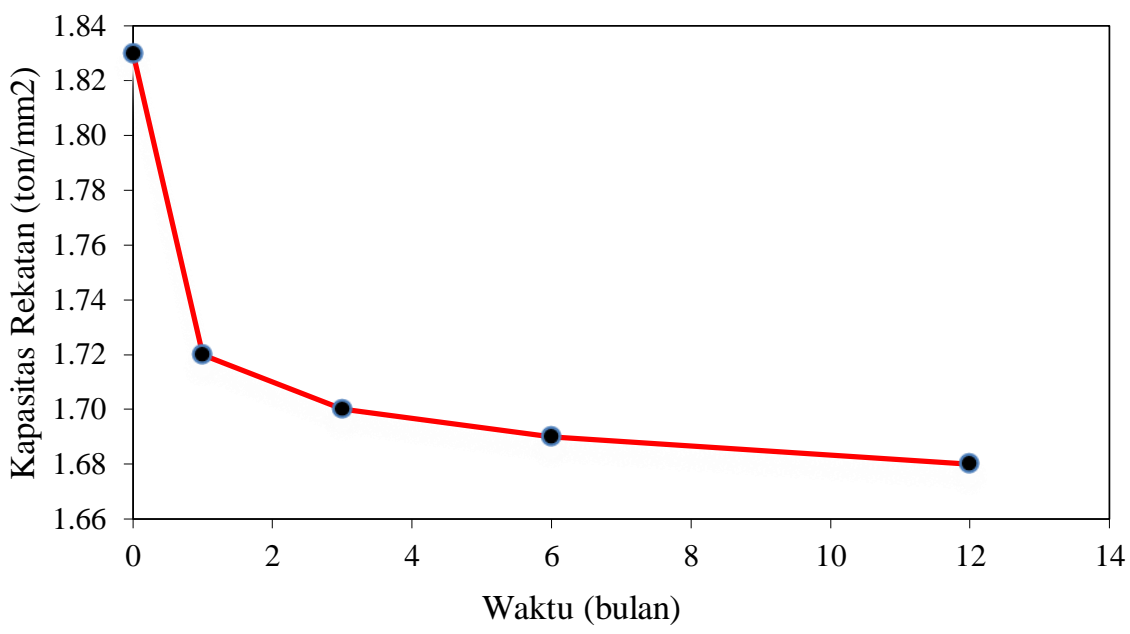

Gambar 9. Kapasitas rekatan GFRP-S setiap benda uji terhadap waktu perendaman

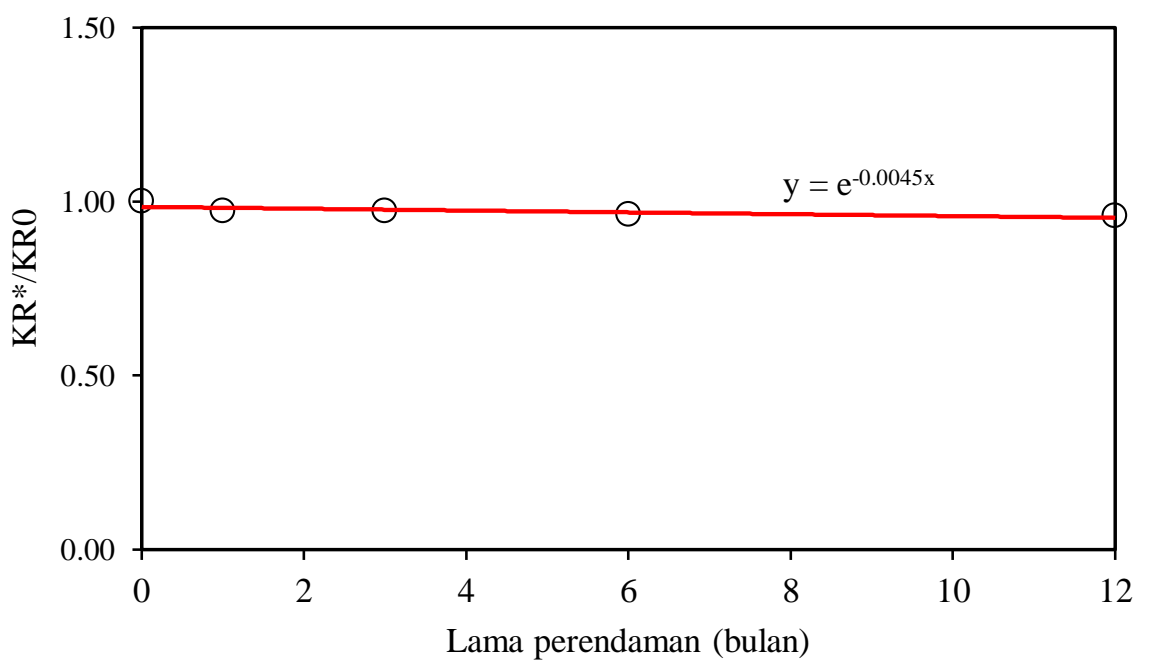

Gambar 10. Pengaruh waktu terhadap rasio kapasitas rekatan GFRP-S

Gambar 9 memperlihatkan bahwa regangan dari GFRP-S akan semakin menurun sering dengan waktu pengaruh rendaman air laut. Hal ini menunjukkan bahwa perkuatan GFRP-S dipengaruhi rendaman air laut yang mengakibatkan kekuatan epoxy semakin berkurang.

Pada beban awal pembebanan, regangan GFRP-S terlihat masih stabil baik untuk $\mathrm{B}_{0}$ maupun $\mathrm{B}_{1}, \mathrm{~B}_{3}$, $\mathrm{B}_{6}$, dan $\mathrm{B}_{12}$. Namun pada beban di mana tulangan mengalami leleh, terlihat jelas perbedaan regangan GFRP-S dari $\mathrm{B}_{1}, \mathrm{~B}_{3}, \mathrm{~B}_{6}$, dan $\mathrm{B}_{12}$ terhadap $\mathrm{B}_{0}$. Kondisi ini terlihat hingga benda uji berada pada kondisi hampir gagal yaitu pada beban masingmasing 4,41 ton, di mana regangan GFRP-S pada $\mathrm{B}_{0}$ lebih besar. Penurunan masing-masing regangan dari $\mathrm{B}_{1}, \mathrm{~B}_{3}, \mathrm{~B}_{6}$, dan $\mathrm{B}_{12}$ terhadap $\mathrm{B}_{0}$ adalah sebesar $19,26 \% ; 22,22 \% ; 22,67 \%$ dan $24,74 \%$. Sementara itu pada kondisi beban maksimum untuk penurunan regangan dari $\mathrm{B}_{1}, \mathrm{~B}_{3}, \mathrm{~B}_{6}$ dan $\mathrm{B}_{12}$ terhadap $\mathrm{B}_{0}$ adalah sebesar $22,33 \% ; 22,51 \% ; 23,26 \%$ dan $23,66 \%$.

Gambar 8 menunjukkan bahwa terjadi penurunan kapasitas rekatan dari benda uji $\mathrm{B}_{1}, \mathrm{~B}_{3}, \mathrm{~B}_{6}$, dan $\mathrm{B}_{12}$ terhadap $\mathrm{B}_{0}$. Adapun nilai kapasitas rekatan yang dihasilkan dari $\mathrm{B}_{0}, \mathrm{~B}_{1}, \mathrm{~B}_{3}, \mathrm{~B}_{6}$, dan $\mathrm{B}_{12}$ adalah $\quad 1,83$ $\mathrm{t} / \mathrm{mm}^{2}, 1,72 \mathrm{t} / \mathrm{mm}^{2}, 1,70 \mathrm{t} / \mathrm{mm}^{2}, 1,69 \mathrm{t} / \mathrm{mm}^{2}$, dan $1,68 \mathrm{t} / \mathrm{mm}^{2}$. Dari data kapasitas rekatan, dapat disimpulkan bahwa terjadi penurunan kapasitas rekatan yang cukup besar, dari dari benda uji $\mathrm{B}_{1}, \mathrm{~B}_{3}$, $\mathrm{B}_{6}$, dan $\mathrm{B}_{12}$ terhadap $\mathrm{B}_{0}$. Persentase penurunan kapasitas rekatan dari dari benda uji $\mathrm{B}_{1}, \mathrm{~B}_{3}, \mathrm{~B}_{6}$, dan $\mathrm{B}_{12}$ terhadap $\mathrm{B}_{0}$, masing-masing adalah $7,85 \%$; $8,89 \%$; 9,33\%; dan $11,04 \%$. Penurunan kapasitas rekatan ini desebabkan menurunnya daya rekat GFRP-S setelah dipengaruhi rendaman air laut. 


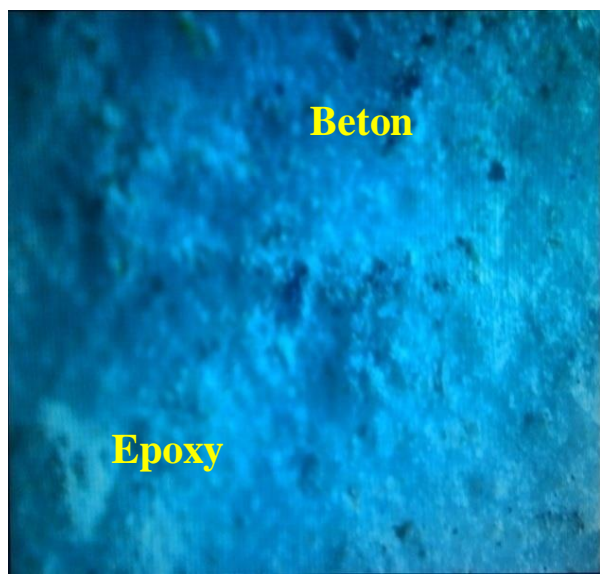

a. Sebelum perendaman

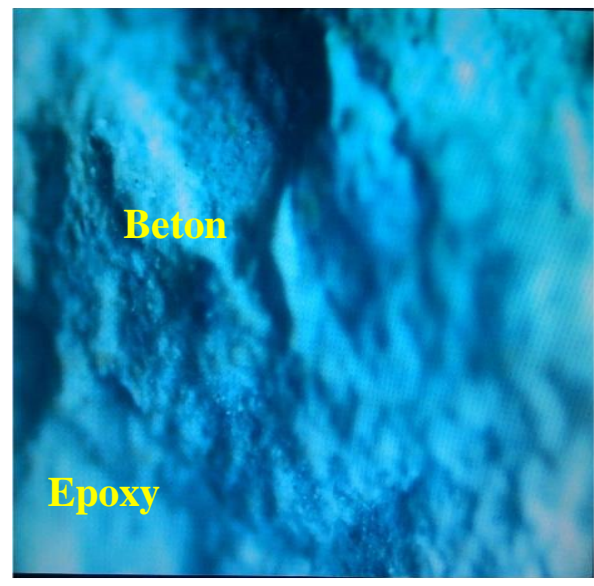

b. Setelah perendaman

Gambar 11. Foto permukaan GFRP-S

\section{Model pengaruh lingkungan laut}

Hubungan antara penurunan kapasitas rekatan dengan waktu rendaman air laut dapat dilihat pada Gambar 9. Rasio perbandingan antara kapasitas rekatan $\mathrm{KR}^{*}$ terhadap KR0 sebesar 1,000; 0,941; 0,931; 0,926 dan 0,924 secara berurutan untuk tanpa perendaman dan lama perendaman satu bulan, tiga bulan, enam bulan, dan 12 bulan ditunjukkan pada Gambar 10.

Rasio kapasitas rekatan (y) terhadap waktu perendaman yang dinyatakan dalam bulan (x) menunjukkan pola kecenderungan garis eksponensial. Persamaan garis eksponensial ini merupakan persamaan korelasi yang menunjukkan hubungan antara kapasitas rekatan terhadap waktu rendaman. Persamaan korelasi ini dapat dilihat dalam persamaan (2).

$y=e^{-0.0045 x}$

Variabel y merupakan perbandingan antara kapasitas rekatan benda uji dengan perkuatan GFRP-S tanpa rendaman air laut dan dengan rendaman air laut dibagi dengan kapasitas rekatan balok normal tanpa rendaman air laut. Untuk lebih jelasnya maka dapat dilihat dalam persamaan (3).

$y=\frac{K R_{t}}{K R_{0}}$

Dengan mensubstitusikan persamaan (2) dan (3) maka dapat diperoleh persamaan baru yaitu persamaan (4).

$K R_{t}=K R_{0} e^{-0,0045 t}$

Untuk mengubungkan antara kolam yang telah diisi dengan air laut dan kondisi laut sebenarnya digunakan faktor FK (Djamaluddin, et al., 2015)

$F K=e^{-0,0140 t}$
Dengan mensubtitusikan nilai FK pada persamaan (4) sehingga diperoleh persamaan (5).

$K R_{t}=K R_{0} e^{-0,0072 t}$

Dimana $\mathrm{KR}_{\mathrm{t}}$ adalah Kapasitas rekatan setelah $\mathrm{t}$ bulan, $\mathrm{KR}_{0}$ adalah Kapasitas rekatan sebelum dipengaruhi rendaman air laut, $\mathrm{t}$ adalah Lama perendaman. Persamaan (4) ini dapat digunakan sebagai prediksi dalam menghitung nilai kapasitas rekatan GFRP-S pada balok rendaman air laut di kolam dan Persamaan (5) digunakan untuk prediksi nilai kapasitas rekatan GFRP-S pada balok rendaman laut. Dimana $\mathrm{KR}_{\mathrm{t}}$ menyatakan kapasitas rekatan GFRP-S setelah direndam dengan air laut selama $\mathrm{t}$ tahun. $\mathrm{KR}_{0}$ kapasitas rekatan GFRP-S sebelum direndam dengan air laut selama t tahun, dengan $\mathrm{t}$ adalah lama perendaman dengan air laut.

\section{Penyebab kegagalan balok perkuatan gfrp-s}

Untuk mengetahui penyebab kegagalan pada balok dengan perkuatan GFRP-S maka dianalisa dengan menggunakan alat petrografi mikroskop polarisasi Olympus BX 51-P.

Dalam Gambar 11a dapat dilihat perbedaan kondisi permukaan GFRP-S setelah dibebani namun belum direndam dengan air laut dan gambar $11 \mathrm{~b}$ di mana kondisi permukaan GFRP-S dibebani dan direndam dengan air laut selama 12 bulan. Luas permukaan beton yang melekat pada GFRP-S sebelum direndam dan setelah direndam selama 12 bulan adalah masing-masing $2,77 \%$ dan $73,00 \%$ terjadi kenaikan luasan beton yang melekat pada GFRP-S sebesar 96,20\% dibandingkan sebelum direndam. Ini mengindikasikan bahwa terjadi perlemahan kohesif antara partikel-partikel pembentuk beton sehingga mempercepat terjadinya debonding yaitu terlepasnya ikatan antara partikel pembentuk beton (delaminasi kohesif). 


\section{Kesimpulan}

Dari hasil penelitian dapat disimpulkan sebagai bahwa akibat pengaruh air laut dapat mempengaruhi kapasitas lentur balok beton bertulang yang telah diperkuat GFRP-S. Penurunan kapasitas lentur ini diakibatkan terjadinya debonding atau terlepas ikatan antara GFRP-S dengan beton. Penyebab terlepasnya ikatan antara GFRP-S dengan beton akibat dari terlepasnya ikatan antara partikel pembentuk beton (delaminasi kohesif). Nilai penurunan kapasitas rekatan antara GRPF-S dengan beton dapat diprediksi dengan menggunakan persamaan $K R_{t}=K R_{0} e^{-0,0072 t}$ dengan $\mathrm{KR}_{\mathrm{t}}$ menyatakan kapasitas rekatan GFRP-S setelah direndam dengan air laut selama $t$ tahun. $\mathrm{KR}_{0}$ kapasitas rekatan GFRP-S sebelum direndam dengan air laut selama $\mathrm{t}$ tahun, $\mathrm{t}$ adalah lama perendaman dengan air laut.

\section{Daftar Pustaka}

Balamuralikrishnan, R. \& Jeyasehar, C. A. (2009). Flexural Behavior of RC Beams Strengthened with Carbon Fiber Reinforced Polymer (CFRP) Fabrics. The Open Civil Engineering Journal, 3, 102-109.

Djamaluddin, R. \& Hino, S. (2011). Flexural Capacity of the Strengthened Yielded Reinforced Concrete Beams using GFRP Sheet. Dinamika Teknik Sipil, 11(3), 293-300.

Djamaluddin, R., Irmawaty, R. \& Kwandou, R. (2015). Kapasitas Rekatan GFRP-S pada Balok Beton Akibat Perendaman Air Laut. Jurnal Teknik Sipil, 22(1), 23-30.

Guo, Z. et al. (2005). Experimental study on bond stress-slip behaviour between FRP sheets and concrete. International Institute for FRP in Construction, 77-84.

Hamid, R. \& Hutchinson, A. (2001). Concrete Beams Strengthened with Externally Bonded FRP Plates. Journal of Composites for Construction, $5(1)$.
Hong, K. N. et al. (2014). Flexural Behavior of RC Members using Externally Bonded AluminumGlass Fiber Composite Beams. Polymers, 6(3), 667-685.

Meikandaan, T. P. \& Murthy, R. (2017). Flexural Behaviour of RC Beam Wrapped. International Journal of Civil Engineering and Technology, 8(2), 452-469.

Mondal, S. \& Gautam, C. P. (2011). Strengthening and Rehabilitation of Reinforced Concrete Beams with Opening. International Journal of Civil and Structural Engineering, 2(1), 127-137.

Park, Y., Kim, Y. H. \& Lee, S. (2014). Long-term Flexural Behaviors of GFRP Reinforced Concrete Beams Exposed to Accelerated Aging Exposure Conditions. Polymers, 6, 1773-1793.

Rose, A. L., Suguna, K. \& Ragunath, P. N. (2009). Strengthening of Corrosion-Damaged Reinforced Concrete Beams with Glass Fiber Reinforced Polymer Laminates. Journal of Computer Science, 5(6), 435-439.

Sultan, M. A. et al. (2015). Effect of Marine Environment to the Concrete Beams Strengthened using GFRP Sheet. International Journal of Engineering and Technology, 7(1), 21-24.

Sultan, M. A. \& Djamaluddin, R. (2017). Pengaruh Rendaman Air Laut terhadap Kapasitas Rekatan GFRP-Sheet pada Balok Beton Bertulang. Jurnal Teknik Sipil, 24(1), 31-43.

Sultan, M. A., Djamaluddin, R. \& Tjaronge, W. (2016). Flexural capacity of concrete beams strengthened using GFRP sheet after seawater immersion. Procedia Engineering, 644-649.

Teng, J. G. \& Chen, J. F. (2007). Debonding Failures of RC Beams Strengthened with Externally Bondded FRP Reinforcement: Behaviour and Modelling Classification of Failure Modes', paper presented at Asia-Pacific Conference on FRP in Structures (APFIS 2007), pp. 33-42. 